\title{
SEXUALIDADE NAS REVISTAS FEMININAS
}

\author{
Patricia F.Cardoso'
}

\section{Introdução}

0 poder dos meios de comunicação, nos processos de mudança nas sociedades contemporâneas, pode estimular ou não a criação das condições propícias à mudança e promover o questionamento, ao contribuir favoravelmente para a mobilização de vontade e recursos para a ação transformadora. As revistas se inserem nesse contexto, por reproduzirem representações disseminadas em determinados grupos, reforçando-as ou gerando outras. Revelam um sistema complexo, já que atuam no cotidiano das pessoas, influenciando seu comportamento, como também podem servir de incentivo a determinados valores e ideologias. As revistas femininas conquistaram seu público-leitor ao informarem sobre as nuanças da satisfação sexual, privilegiando o sexo não-reprodutivo (o sexo-prazer).

Por estarem atentas às necessidades do público-leitor, as revistas Claudia, Marie Claire e Nova foram escolhidas como referência neste estudo, por apresentarem semelhanças e especifidades no conteúdo editorial, além de atingirem em torno de 3 milhões de leitoras. 


\section{Objetivos}

Verificar os valores, crenças e ideologias constantes nas principais revistas dirigidas ao público feminino, além do papel informativo e formativo que desempenham no que concerne aos papéis sexuais e ao comportamento sexual feminino.

Relevância Social: A imprensa feminina participou do processo de conquistas da mulher por permitir, através da acessibilidade à informação, novos modelos culturais e comportamentais. Nas revistas da atualidade, a abordagem da sexualidade não está inserida em uma esfera secundária. Procuram atender às necessidades de informação, abrindo espaço para questionamentos e novas propostas condizentes com as mudanças sociais. Com a participação dos especialistas em diversos campos de atuação (bio-psico-social), as revistas se esforçam no esclarecimento às dúvidas das leitoras, respaldadas pelo conhecimento de seus colaboradores.

Métodos e Resultados: Consideradas sobre a ótica da teoria da aprendizagem social de Bandura, com ênfase na função do reforço para a aquisição ou modificação do comportamento, foram estudadas as revistas Claudia, Marie Claire e Nova, num total de 132 exemplares, em seu aspecto informativo e formativo concernente à sexualidade. Utilizouse a análise quantitativa (frequência de ocorrências dos temas pesquisados), abrangendo o número de anos, classificados em categorias, e a análise qualitativa (análise de conteúdo) dos dados levantados.

Os resultados indicaram a influência da publicidade nos textos e imagens utilizados para a modificação de crenças, valores e atitudes que interferem de forma negativa na sexualidade e o reforço de atitudes positivas para se alcançar uma vida sexual satisfatória. Estereotipias e antigos conceitos são discutidos, ao mesmo tempo em que há o reforço ao clássico desejo feminino de agradar aos homens e, por essa razão, o consumo de produtos é bastante exigido, reforçando a imagem da mulher como fêmea erótica: compre e seduza. 


\section{Conclusão}

0 discurso baseia-se no direito de a mulher exercer sua sexualidade e reformular seus conceitos. Sendo o sexo uma questão social, procuram levar a leitora à reflexão sobre as individualidades e, através da abordagem de temas polêmicos, ser capaz de desenvolver um pensamento crítico. Estabelecendo um diálogo com as leitoras, essas publicações interferem na intimidade das mulheres, mostrando o que, em tempos atuais, precisa ser revisto na esfera sexual. 0 número de publicações aumentou, bem como a frequência dos temas ligados à sexualidade. Além disso, instalou-se uma abertura maior para a discussão desse tema, principalmente em referência ao prazer. As leitoras participam, inclusive, de pesquisas sobre questões sexuais, via internet.

Esta pesquisa evidencia o grande impacto social dessas três revistas ao promoverem a discussão da sexualidade em um universo caracterizado pela falta de informação nas instituições clássicas (escola e família). 